Article

\title{
Kaolinite Claystone-Based Geopolymer Materials: Effect of Chemical Composition and Curing Conditions
}

\author{
Pavlína Hájková ${ }^{D}$ \\ Unipetrol Centre for Research and Education, Revoluční 84, 40001 Ústí nad Labem, Czech Republic; \\ pavlina.hajkova@unicre.cz; Tel.: +420-475-309-218
}

Received: 24 August 2018; Accepted: 3 October 2018; Published: 11 October 2018

\begin{abstract}
This work describes the role of chemical composition and curing conditions in geopolymer strength, leachability of chemical elements and porosity. The study focuses on geopolymer material prepared from calcined kaolinite claystone, which is not studied frequently as a raw material for geopolymer production, although it has a high application potential as it is easily commercially available and allows preparation of geopolymers with low viscosity. The composition of geopolymers and their curing methods were selected considering their ease of use in the praxis. Therefore, the potassium water glass itself was used as alkali activator without any $\mathrm{KOH}$ or $\mathrm{NaOH}$ addition. Chemical composition was changed only by the density of water glass in the range of 1.2 to $1.6 \mathrm{~g} \cdot \mathrm{cm}^{-3}$. Geopolymers were cured at a temperature within the range of $5{ }^{\circ} \mathrm{C}-70{ }^{\circ} \mathrm{C}$ to speed up the solidification process as well as by microwave radiation. High compressive strengths were obtained for geopolymers with the highest densities of the water glass $\left(1.5\right.$ and $\left.1.6 \mathrm{~g} \cdot \mathrm{cm}^{-3}\right)$ in dependence on various curing conditions. Higher strengths were achieved in the case of samples where the solidification was not accelerated. The samples cured at lower temperatures $\left(5^{\circ} \mathrm{C}\right)$ showed lower porosity compared to the other curing types. The lowest leachability of Si and alkalis was reached for the samples with water glass density $1.5 \mathrm{~g} \cdot \mathrm{cm}^{-3}$.
\end{abstract}

Keywords: geopolymer; claystone; leachability; compressive strength; porosity

\section{Introduction}

New technologies, increasing environmental demands, and demands on the new products quality create pressure on the research and development of new materials. These materials must fulfill often contradictory demands and low cost. One interesting group of materials is geopolymers. The geopolymers have high strength and are stable at high temperatures (over $1000{ }^{\circ} \mathrm{C}$ ). These are low-cost materials and carry a low environmental burden. The term "geopolymer" was first used by Davidovits in 1978 [1] to specify a new class of 3-dimensional aluminosilicate materials. Nevertheless, the history of alkali-activated cement is dated to the 1940s by Glukhovsky and then Krivenko [2,3]. Geopolymers (GP in the following text) are formed by alkaline activation of thermally treated aluminosilicate material like fly ash [4-7], furnace slag [8-10], kaolinite clay [11-13] etc. A reaction called geopolymerization creates polymeric Si-O-Al bonds in a three-dimensional network [14]. The ratio of silicon and aluminum influences the properties of the geopolymers. The negative charge of alumina tetrahedrons is balanced by the presence of alkali-metal ions, commonly $\mathrm{Na}^{+}, \mathrm{K}^{+}$or $\mathrm{Ca}^{+}[14]$. Several investigations considering the precursors' composition and curing conditions have been done $[8,15,16]$.

Most of the literature is focused on the comparison of the strength of the GPs prepared from fly ash or kaolin originated metakaolin cured at elevated or ambient temperature [4,5,17-19]. Studies [20,21] 
deal with the strengths of GPs treated by microwave radiation after solidification while study [22] deals with the effect of the curing temperature in a range of $10-80{ }^{\circ} \mathrm{C}$. In this work, we focused on geopolymers prepared from kaolinite claystone originated metakaolin and microwaves were used as a tool for the solidification itself. Lowered curing temperature was also used which is important in case of outdoor use. Leachability and porosity were studied as well.

The simplicity of the preparation process is very important for industrial production as well as the viscosity of the GP. This study is focused on the preparation with alkali activator containing only water glass to simplify the production process contrary to the most of the other studies $[3,4,16,22,23]$ where a combination of $\mathrm{NaOH} / \mathrm{KOH}$ and water glass (alkali silicate) is used as a most common alkaline liquid for geopolymerization.

The GP composition was changed only by the water glass density (i.e., by changes of the water/Si/K content). The GPs were prepared from commercially available raw materials_potassium water glass with silicate modulus M1.7, from calcined and finely milled kaolinite claystone and from calcium hydroxide $\left(\mathrm{Ca}(\mathrm{OH})_{2}\right)$.

The composition of the geopolymers was chosen with respect to the easiness of the preparation and with the aim of reaching the high compressive strength. As mentioned in $[2,24,25]$, compressive strength of metakaolin-based geopolymers increased significantly from $\mathrm{Si} / \mathrm{Al}=1.15$ to $\mathrm{Si} / \mathrm{Al}=1.90$. As proposed in [2] more factors such as the $\% \mathrm{CaO}, \% \mathrm{~K}_{2} \mathrm{O}$ and the type of alkali have a significant correlation with compressive strength. Moreover the compressive strength of geopolymers depends on a number of factors including gel phase strength, the ratio of the gel phase/undissolved $\mathrm{Al}-\mathrm{Si}$ particles, the distribution and the hardness of the undissolved Al-Si particle sizes, the amorphous nature of geopolymers or the degree of crystallinity as well as the surface reaction between the gel phase and the undissolved Al-Si particles $[2,5,26,27]$. Based on these factors, the GPs with molar ratio $\mathrm{Si}: \mathrm{Al}=1.4-1.85$, constant ratio $\mathrm{Ca}: \mathrm{Al}=0.12$ and ratio $\mathrm{K}_{2} \mathrm{O}: \mathrm{Al}_{2} \mathrm{O}_{3}=0.454-1[2,24,25]$ were used.

Finely milled calcined kaolinite claystone is easily available commercial material (e.g., Mefisto L05 delivered by České lupkové závody a.s., Nové Strašecí, Czech Republic). The material is prepared from mined kaolinite claystone with sufficient $\mathrm{Al}_{2} \mathrm{O}_{3}$ content. This is sedimentary rock, which usually occurs as underclay. This material was used due to its higher bulk density $\left(493 \mathrm{~g} \cdot \mathrm{cm}^{-3}\right)$ compared to calcined kaolin with the same particle size $\left(377 \mathrm{~g} \cdot \mathrm{cm}^{-3}\right)$ (e.g., Mefisto K05, České lupkové závody a.s., Nové Strašecí, Czech Republic) which allows one to prepare a GP matrix with lower viscosity. The increased specific surface of the calcined kaolinite claystone $\left(12.7 \mathrm{~m}^{2} \cdot \mathrm{g}^{-1}\right.$ compared to $10.2 \mathrm{~m}^{2} \cdot \mathrm{g}^{-1}$ for calcined kaolin) can also ensure better solubility in the alkali activator. The influence of the particle size is very important too and is described in $[2,5,26,27]$.

Individual samples had various curing conditions-either temperature was varied from 5 to $70^{\circ} \mathrm{C}$ or the microwave (MW) radiation was used which enables fast removal of the sample from the casting mold. The strength as well as the porosity and leachability of various elements were measured in order to decrease efflorescence.

\section{Materials and Methods}

Metakaolin for geopolymer concretes was made from kaolinite claystone calcined in a rotary kiln at $750{ }^{\circ} \mathrm{C}$ and subsequently finely milled (Mefisto L05 delivered by České lupkové závody a.s., Nové Strašecí, Czech Republic). Other components of geopolymers were commercial potassium water glass with molar ratio $\mathrm{SiO}_{2} / \mathrm{M}_{2} \mathrm{O}$ equal to 1.7 (DVS 1.7 delivered by Vodní sklo, a.s.) and calcium hydroxide $\left(\mathrm{Ca}(\mathrm{OH})_{2}\right.$ produced by Vápenka Čertovy schody, a.s., Tmaň, Czech Republic). The density of the water glass DVS 1.7 diluted with distilled water lied within the range of 1.2 to $1.6 \mathrm{~g} \cdot \mathrm{cm}^{-3}$ and was controlled by a pycnometric method.

The chemical composition (measured by XRF) and loss of ignition (LOI) for the calcined kaolinite claystone as well as the chemical composition (measured by ICP and titration method) and content of water for the potassium water glass can be seen in Table 1 . The particle size distribution is shown in Figure 1, the particle size was ranged between 0.2 and $12.0 \mu \mathrm{m}$ while median-diameter $\left(\mathrm{D}_{50}\right)$ was 
$4.32 \mu \mathrm{m}$. The XRD structures of kaolinite claystone before and after calcination are shown in Figure 2a. The major phase before calcination was kaolinite, minor phases were quartz and illite. After calcination only one crystalline phase-quartz is found. SEM micrograph of the metakaolin prepared from kaolinite claystone (Figure 2 b) revealed that the metakaolin was platy. It had a surface area equal to $12.7 \mathrm{~m}^{2} \cdot \mathrm{g}^{-1}$ according to the BET analysis.

Table 1. Chemical composition of the calcined kaolinite claystone (wt \%) and potassium water glass DVS1.7.

\begin{tabular}{|c|c|c|c|c|c|c|c|c|c|c|c|}
\hline $\begin{array}{l}\text { Chemical Composition } \\
\text { (wt \%) }\end{array}$ & $\mathrm{MgO}$ & $\mathrm{Al}_{2} \mathrm{O}_{3}$ & $\mathrm{SiO}_{2}$ & $\mathbf{P}_{2} \mathbf{O}_{5}$ & $\mathrm{SO}_{3}$ & $\mathrm{~K}_{2} \mathrm{O}$ & $\mathrm{Na}_{2} \mathrm{O}$ & $\mathrm{CaO}$ & $\mathrm{TiO}_{2}$ & $\mathrm{Fe}_{2} \mathrm{O}_{3}$ & LOI $\mathrm{H}_{2} \mathrm{O}$ \\
\hline $\begin{array}{c}\text { Calcined kaolinite claystone } \\
\text { Water glass }\end{array}$ & 0.13 & 41.45 & $\begin{array}{l}52.03 \\
27.75\end{array}$ & 0.06 & 0.20 & $\begin{array}{c}0.79 \\
26.17\end{array}$ & 1.11 & 0.15 & 1.62 & 1.05 & $\begin{array}{c}2.52 \\
44.97\end{array}$ \\
\hline
\end{tabular}

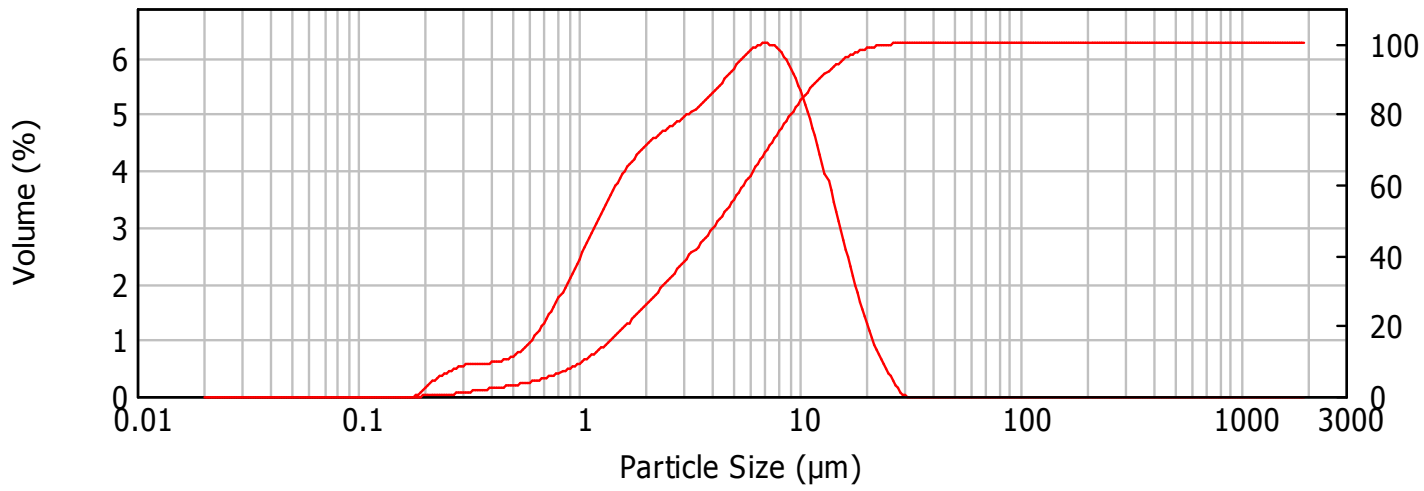

Figure 1. Particle size distribution of the metakaolin prepared from calcined kaolinite claystone measured by laser diffraction.

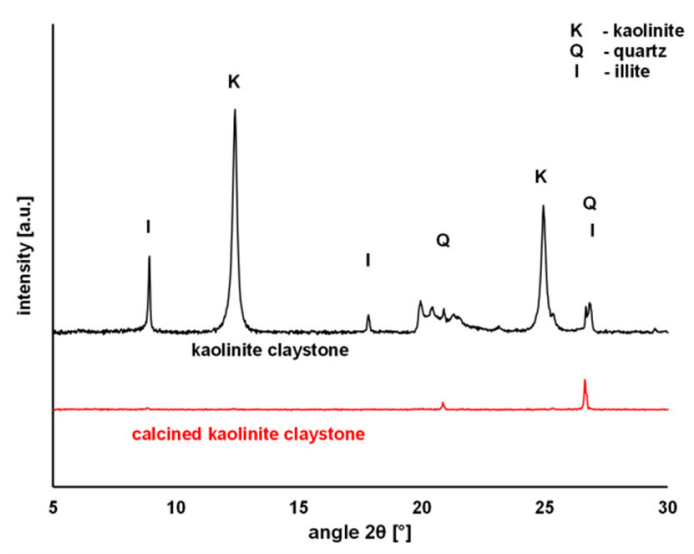

(a)

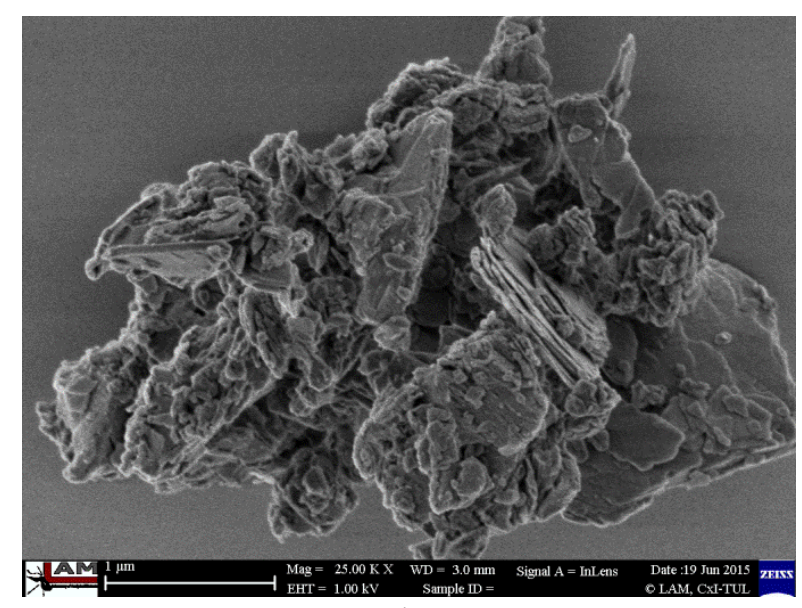

(b)

Figure 2. (a) XRD patterns of kaolinite claystone before and after calcination; (b) SEM of the metakaolin prepared from calcined kaolinite claystone. The scale bar is $1 \mu \mathrm{m}$ long.

Fine quartz sand delivered by Sklopísek Střeleč, a.s. company, Újezd pod Troskami, Czech Republic (grain $0.063-0.40 \mathrm{~mm}$, median-diameter $0.14 \mathrm{~mm}$ ) was used as a reinforcement [28].

\subsection{Specimen Preparation}

Initially, the GP was prepared through two steps. At first, a GP binder was prepared by mixing water glass, metakaolin from kaolinite claystone and calcium hydroxide for 5 min at room temperature $\left(22{ }^{\circ} \mathrm{C}\right)$. Weight ratio water glass: kaolinite: calcium hydroxide was kept constant for all samples. The only changed parameter was water glass density. After that, the binder was mixed for another $5 \mathrm{~min}$ with the fine quartz sand at weight ratio 1:1. The mixture was cast into the cylindrical silicone 
molds with dimensions (diameter $\times$ height) $30 \times 60 \mathrm{~mm}$. Five variants of GP were prepared with various water glass densities, i.e., $1.2,1.3,1.4,1.5$ and $1.6 \mathrm{~g} \cdot \mathrm{cm}^{-3}$. Chemical composition (calculated from the precursor's amounts) of prepared geopolymers is listed in Table 2. The sample preparation was finished using six different curing methods which are summarized in Table 3 and described below in detail. The sample curing included various temperatures and also microwave treatment which can improve the GP properties after hardening as was shown in the literature [20-23]. The methods used for curing were: (1) solidification at ambient temperature; (2) at elevated temperature $\left(70{ }^{\circ} \mathrm{C}\right)$; (3) at reduced temperature in a fridge $\left(5^{\circ} \mathrm{C}\right) ;(4)$ at varying temperature $\left(12 \mathrm{~h}\right.$ at $5{ }^{\circ} \mathrm{C}$ followed by $6 \mathrm{~h}$ at ambient temperature) and two types of curing using microwaves-(5) the MW applied immediately after casting the GP (which shortened the time needed for hardening from $12 \mathrm{~h}$ to 26 min and (6) the MW used the second day after solidification at ambient temperature. The MW oven was operated at power $3 \mathrm{KW}$ in cyclic mode (0.8 s power on and 10 s power off, 200 cycles) at frequency $2.45 \mathrm{GHz}$.

Table 2. Chemical composition of the geopolymers.

\begin{tabular}{ccccccc}
\hline \multirow{2}{*}{ Geopolymer } & Water Glass Density $\left(\mathbf{g} \cdot \mathbf{c m}^{-3}\right)$ & \multicolumn{5}{c}{ Total Molar Ratio } \\
\cline { 3 - 6 } & & Si:Al & M:Al & $\mathbf{H}_{\mathbf{2}}$ O:Al & K:Na & Ca:Al \\
\hline GP1.2 & 1.2 & 1.40 & 0.48 & 8.61 & 16.12 & 0.12 \\
GP1.3 & 1.3 & 1.54 & 0.66 & 7.71 & 15.95 & 0.12 \\
GP1.4 & 1.4 & 1.65 & 0.82 & 6.93 & 15.87 & 0.12 \\
GP1.5 & 1.5 & 1.76 & 0.95 & 6.25 & 15.82 & 0.12 \\
GP1.6 & 1.6 & 1.85 & 1.06 & 5.66 & 15.78 & 0.12 \\
\hline
\end{tabular}

Table 3. Curing conditions of the geopolymers.

\begin{tabular}{ccc}
\hline Label & Curing Methods & Time to Hardening \\
\hline $\mathrm{LT}$ & solidify at ambient temperature in laboratory $\left(22^{\circ} \mathrm{C}\right)$ & $12 \mathrm{~h}$ \\
$70^{\circ} \mathrm{C}$ & solidify at $70{ }^{\circ} \mathrm{C}$ during $3 \mathrm{~h}$ & $3 \mathrm{~h}$ \\
$\mathrm{MW} / 2$ & solidify at ambient temperature and 2 nd day 26 min at microwave radiation & $12 \mathrm{~h}$ \\
$\mathrm{MW}$ & solidify 26 min at microwave radiation & $26 \mathrm{~min}$ \\
$5{ }^{\circ} \mathrm{C} / \mathrm{LT}$ & solidify at $5{ }^{\circ} \mathrm{C}$ during $12 \mathrm{~h}$ and then at ambient temperature in laboratory $\left(22{ }^{\circ} \mathrm{C}\right)$ & $18 \mathrm{~h}$ \\
$5^{\circ} \mathrm{C}$ & solidify at $5{ }^{\circ} \mathrm{C}$ & $24 \mathrm{~h}$ \\
\hline
\end{tabular}

\subsection{Characterization}

The elemental composition of calcined kaolinite claystone was determined by X-ray fluorescence using XRF Bruker S8 Tiger equipped with an Rh RTG lamp (Bruker, Billerica, MA, USA). Loss on ignition was set as loss of weight of the dried sample at $1000{ }^{\circ} \mathrm{C}$. The specific surface area was measured by nitrogen physisorption at $-196^{\circ} \mathrm{C}$ using Autosorb iQ from Quantachrome company sorption analyzer (Anton Paar GmbH, Graz, Austria). The particle size distribution was determined by laser diffraction MASTERSIZER 2000 (Malvern Panalytical Ltd, Malvern, UK). The density of potassium water glass was determined by a pycnometric method and its chemical composition by titration and by inductively coupled plasma optical emission spectrometry (ICP-OES Optima 8000, Perkin Elmer, Waltham, MA, USA). The crystallographic structure of raw and calcined kaolinite claystone was determined by X-ray powder diffraction using a Bruker D8 Advance ECO, working with the $\mathrm{Cu}$ anode.

The compressive strength was measured after 7 and 28 days using LabTest 6.200 (Labor Tech, Opava, Czech Republic). Before the measurement, the samples were ground to have plain parallel surfaces. The aim of the leaching investigation was to determine the leachability of the main structural elements ( $\mathrm{Si}, \mathrm{Al}, \mathrm{K}, \mathrm{Na}$ ) and its dependence on curing methods and on the chemical composition of geopolymers. Leachability was tested after 28 days according to standard EN 12457-4. The leachable elements concentrations were determined using ICP-OES Optima 8000 Perkin Elmer. The results were related to $1 \mathrm{~g}$ of the geopolymer. Pore size distributions of two series of geopolymers were determined using an AutoPore IV 9510 mercury intrusion porosimeter (Micromeritics Instrument Corp., Norcross, GA, USA), which operates with pressures from $0.01 \mathrm{MPa}$ to $414 \mathrm{MPa}$. The first series comprised 
of geopolymers with a whole range of water glass densities solidified at ambient temperature and the second series were geopolymers with water glass density $1.5 \mathrm{~g} \cdot \mathrm{cm}^{-3}$ with all 6 possibilities of curing conditions.

\section{Results and Discussion}

\subsection{Compressive Strength}

The influence of the curing conditions on the resulting compressive strength was studied for samples with various water glass densities as well as on the compressive strength during 28 days of maturation of the GPs (Figure 3). In the case of 7 and 28 days old GPs, the difference is the biggest for GPs cured by low temperature $\left(5^{\circ} \mathrm{C}, 5{ }^{\circ} \mathrm{C} / \mathrm{LT}\right)$. The low temperature causes slower maturation and, therefore, longer compressive strength development. The slower maturation gave the most positive results in the cases of samples GP1.3, GP1.4 and GP1.5, where the strength after 28 days reached the highest values of all modifications (within one sample series with the same water glass density).

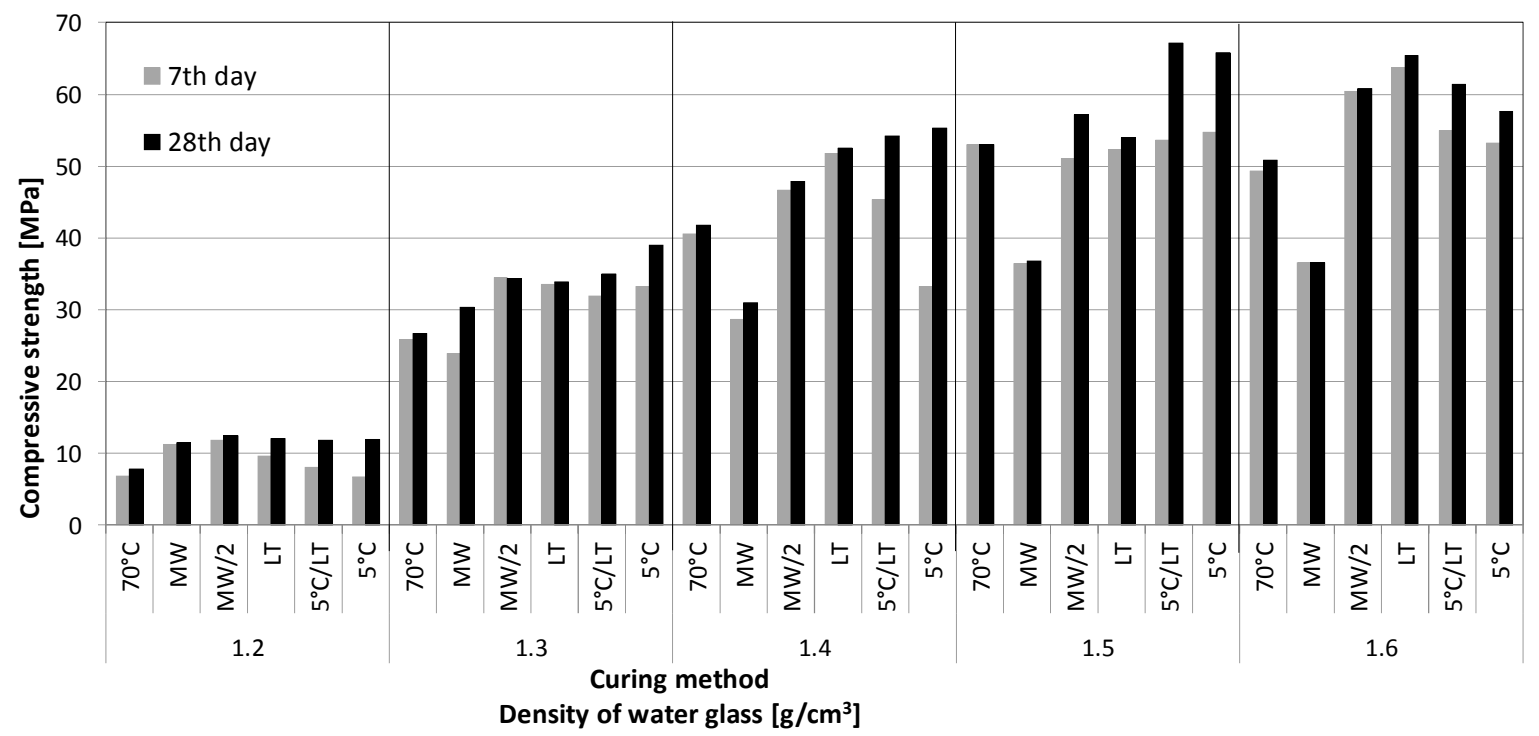

Figure 3. Influence of curing method and density of water glass on the compressive strength of geopolymers. Values were averaged from 5 measurements. The standard deviation was under $10 \%$ of the average value.

As expected and described in [29], the compressive strength increases with higher water glass density. The lowest compressive strengths were found in case of GPs with water glass densities 1.2 and $1.3 \mathrm{~g} \cdot \mathrm{cm}^{-3}$ with accelerated solidification at elevated temperature, i.e., at $70{ }^{\circ} \mathrm{C}$ (influence of $\mathrm{MW}$ radiation is discussed separately later). This could be related to a lower degree of geopolymerization caused by the higher velocity of the polymerization reaction. This is demonstrated in Figure 4, where the leachabilities are grouped by a method used for curing. The solidification at $70{ }^{\circ} \mathrm{C}$ seems to have the highest leachabilities of $\mathrm{Si}$ and $\mathrm{Al}$ from all of the curing methods.

The lowest compressive strength was found in case of the GPs with water glass densities $1.4-1.6 \mathrm{~g} \cdot \mathrm{cm}^{-3}$, where MW curing was used immediately after the casting to the mold. Possibly the higher ions content (and therefore higher conductivity) could cause a problem under MW radiation and could lead to local overheating of the liquid during the MW treatment and created more pores resulting in lowered compressive strength. This was confirmed by porosimetry measurements, which's results are discussed later. 


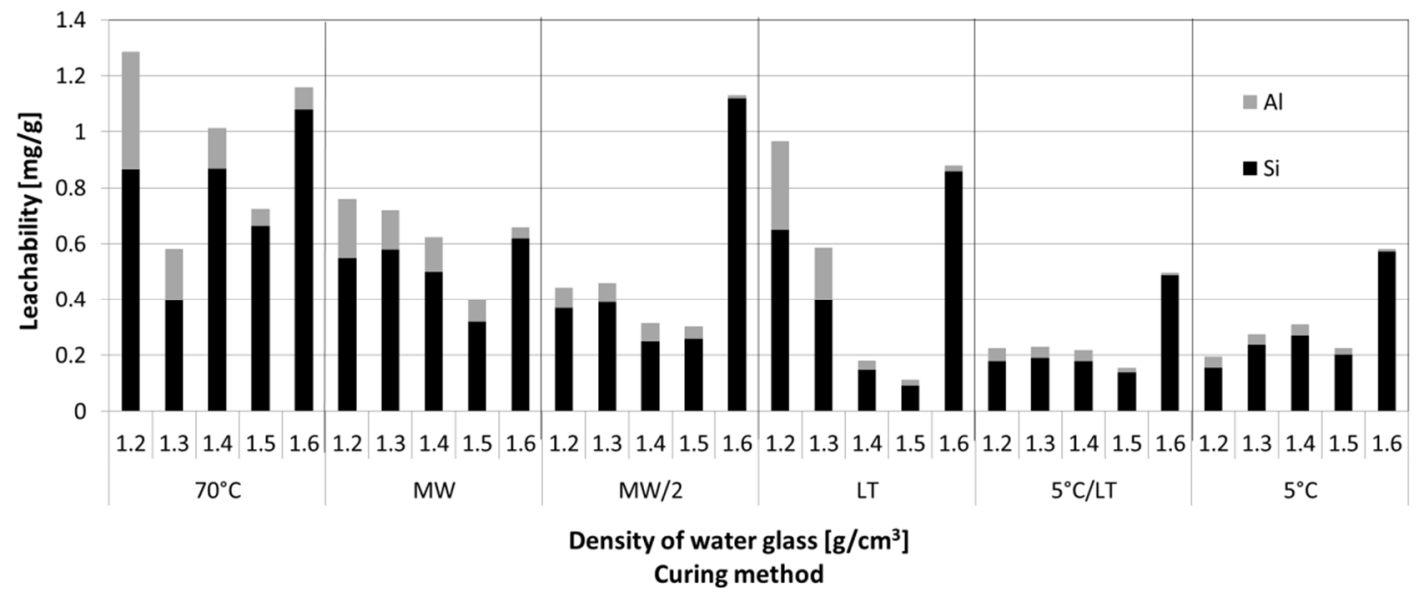

Figure 4. Influence of treatment type and density of water glass on the leachability of $\mathrm{Al}$ and Si.

In case of MW/2 sample, the microwave radiation was used after solidification of the GP with the aim of increasing its compressive strength — the MW/2 treatment was shown [19] to increase the GP compressive strength compared to the elevated temperature treatment at $75^{\circ} \mathrm{C}$. It was confirmed also in this work, where an increase of the compressive strength compared to the $70{ }^{\circ} \mathrm{C}$ was observed. The comparison of the MW/2 and LT sample did not show any significant differences. The most surprising result was obtained for both low-temperature treatments $\left(5^{\circ} \mathrm{C}\right.$ and $\left.5{ }^{\circ} \mathrm{C} / \mathrm{LT}\right)$. The low-temperature curing resulted in the highest compressive strengths in the case of GP1.3 and GP1.4. The GP1.5 combined with the $5{ }^{\circ} \mathrm{C} / \mathrm{LT}$ treatment reached the highest compressive strength at all.

We assume that the slower solidification (longer presence of liquid phase) provided a longer time for geopolymer chains creation which resulted in lower number of the pores (porosity is discussed in detail in Section 3.3.), lower leachability and higher compressive strength. This was confirmed also by the leachability tests (Figure 4), which showed the lowest values right for the GPs treated at a lower temperature (samples $5{ }^{\circ} \mathrm{C}$ and $\left.5{ }^{\circ} \mathrm{C} / \mathrm{LT}\right)$. But the fast solidification $\left(70^{\circ} \mathrm{C}\right.$ and MW treatment) seem to force the polymerization to stop quickly which results in lower compressive strength values. On the other hand, the serial production demands the fast removal of the GP product from the mold and when the MW radiation is used, the product can be removed after several tens of minutes depending on its volume and shape.

The GP1.4 and GP1.5 solidified at LT did not show any difference in the compressive strength. This result is very important for practical use, where the best compromise between low viscosity/high strength/low cost must be chosen.

\subsection{Leachability Tests}

The leachability of the elements from matured GPs can give information on the proper polymerization of the GP. The leachabilities of structural elements of the GP, $\mathrm{Al}$, and $\mathrm{Si}$, was measured and also the leachability of the $\mathrm{K}^{+}$and $\mathrm{Na}^{+}$ions (given in sum as $\mathrm{M}$ ) which can cause unwanted efflorescences was studied. The leachabilities of $\mathrm{Si}$ and $\mathrm{Al}$ and the influence of the water glass density and type of the following treatment are shown in Figure 4. The increasing water glass density results in higher Si content in the GP and a lower content of water. The leachability of the Si in most of the treatments decreases with the water glass density, but at $1.6 \mathrm{~g} \cdot \mathrm{cm}^{-3}$ sudden increase is found. The only exception is the $70{ }^{\circ} \mathrm{C}$ treatment where the lowest leachability has the sample GP1.3. The GPs treated at $70{ }^{\circ} \mathrm{C}$ also show the highest leachabilities of $\mathrm{Si}$ and $\mathrm{Al}$ from all of the treatments. The leachability of $\mathrm{Al}$ for all types of treatment decreases with increasing water glass density. In case of lower water glass densities (GP1.2 and GP1.3), the microwave treatment used the second day after solidification at ambient temperature (MW/2) significantly decreases leachability of the $\mathrm{Al}$ compared to treatment only at ambient temperature (LT). The most interesting is the sudden change of leachability of Si. 
It is probable that the GP1.6 has already too low content of water (important for the process of geopolymerization). The optimal (from the leachability and compressive strength point of view) molar ratio of Si:Al often seen in the literature is equal to $2[25,30,31]$. However, this is valid for GP created from metakaolin prepared from kaolin. The other possibility is to prepare the metakaolin from the kaolinitic claystone-which is the case of this study. The optimal Si:Al ratio obtained for this source material seems to be different—-the best results were obtained for GP 1.5 where the Si:Al molar ratio is equal to 1.76 as demonstrated earlier. Why is this difference present? The molar ratio is calculated from the amounts of the precursors, nevertheless, it does not mean that such ratio is preserved in resulting GP gel. The reason can be, e.g., that the metakaolin is not completely dissolved [32,33]. The metakaolin is the only source of the Al contrary to the $\mathrm{Si}$, which is also contained in the water glass. The ideal ratio $\mathrm{Si}$ Al cannot be exactly the same for all GPs because it is dependent on used raw materials, namely on the size and shape of the grains [5] and on the solubility of the aluminosilicate materials in given alkali environment $[2,26]$. This work indicates the best structure and the best ratio Si:Al equal 1.76 for the kaolinite claystone based GP. In order to address the interesting sudden change in the leachability in case of LT treatment, further research needs to be carried out (e.g., NMR measurements).

The influence of the water glass density and type of the treatment on the leachability of various elements $\left(\mathrm{K}^{+}\right.$and $\mathrm{Na}^{+}$is given as sum and labeled $\left.\mathrm{M}\right)$ is shown in Figure 5. The increasing water glass density results in higher amount of ions in the GP. A noticeable increase of the leachability can be seen again for GP1.6 for almost all types of the treatment. This was probably because of low water content, which is important for the migration of ions in process of geopolymerization.

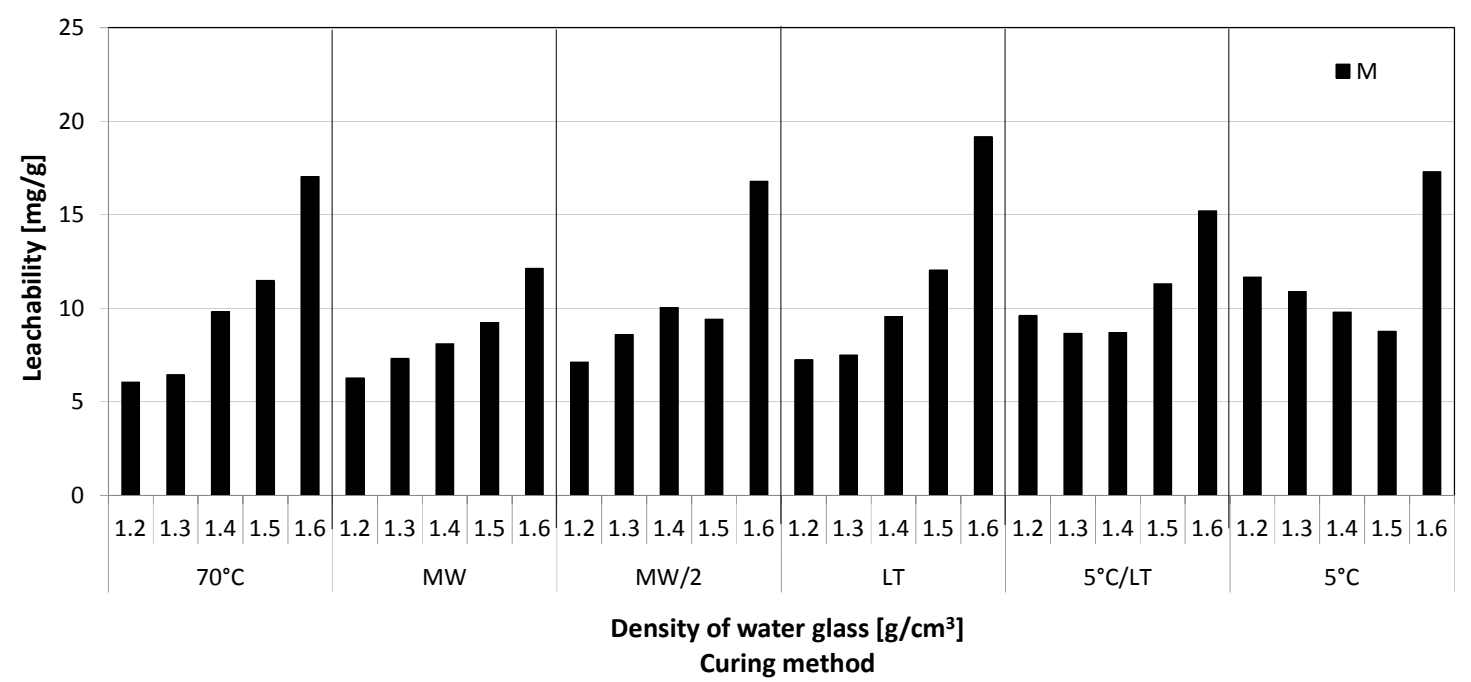

Figure 5. Influence of treatment type and density of water glass on leachability of sum $\mathrm{K}^{+}$and $\mathrm{Na}^{+}$ (labeled as M).

\subsection{Porosity}

The mercury intrusion porosimetry was performed to determine the pore distribution in studied GPs. Table 4 and Figure 6 represent the development of pores in GPs cured at ambient temperature made from water glass density within the range of $1.2-1.6 \mathrm{~g} \cdot \mathrm{cm}^{-3}$. Total pore volume lowers with increasing water glass density, i.e., with lower water content, which is in agreement with [34]. The GP with water glass density $1.6 \mathrm{~g} \cdot \mathrm{cm}^{-3}$ has 2 times smaller pore volume compared to the one with water glass density $1.2 \mathrm{~g} \cdot \mathrm{cm}^{-3}$. The polymers GP1.2 and GP1.6 have the widest pore size distribution function.

Development of the pore sizes for samples GP1.5 cured at different conditions is presented in Table 5 and Figure 7. It is obvious that the treatment type does not affect the average pore diameter neither the pore diameter distribution significantly. Tested GPs had pores in the range of mesopores, the diameters were between 10-20 nm. The curing conditions however influenced the total pore 
volume. This is in agreement with Rovnaník [22], where increased pore volume was confirmed as well as lower compressive strength with increasing curing temperature. The largest pore volume was obtained in case of the MW treatment immediately after the casting of the GP into the mould. The MW radiation probably caused local overheating of the liquid resulting in creation of bigger number of the pores and therefore in lowering the compressive strength as was discussed earlier.

Table 4. Dependence of porosity on water glass density for geopolymers cured at ambient temperature.

\begin{tabular}{cccccc}
\hline Water Glass Density $\left(\mathrm{g} \cdot \mathrm{cm}^{-3}\right)$ & $\mathbf{1 . 2}$ & $\mathbf{1 . 3}$ & $\mathbf{1 . 4}$ & $\mathbf{1 . 5}$ & $\mathbf{1 . 6}$ \\
\hline Pore Volume $\left(\mathrm{mm}^{3} \cdot \mathrm{g}^{-1}\right)$ & 166.9 & 143.5 & 122.7 & 94.2 & 75.8 \\
Average Pore Diameter $(\mathrm{nm})$ & 32.4 & 16 & 16.5 & 19 & 47.2 \\
\hline
\end{tabular}

Table 5. Dependence of porosity on cured methods for geopolymers with water glass density $1.5 \mathrm{~g} \cdot \mathrm{cm}^{-3}$.

\begin{tabular}{ccccccc}
\hline Curing Method & $\mathbf{7 0}^{\circ} \mathbf{C}$ & MW & MW/2 & LT & $\mathbf{5}^{\circ} \mathbf{C} / \mathbf{L T}$ & $\mathbf{5}^{\circ} \mathbf{C}$ \\
\hline Pore Volume $\left(\mathrm{mm}^{3} \cdot \mathrm{g}^{-1}\right)$ & 104.1 & 110.7 & 100.5 & 94.2 & 81.4 & 73.3 \\
Average Pore Diameter $(\mathrm{nm})$ & 15.4 & 16.9 & 14.5 & 19.0 & 17.6 & 19.2 \\
\hline
\end{tabular}

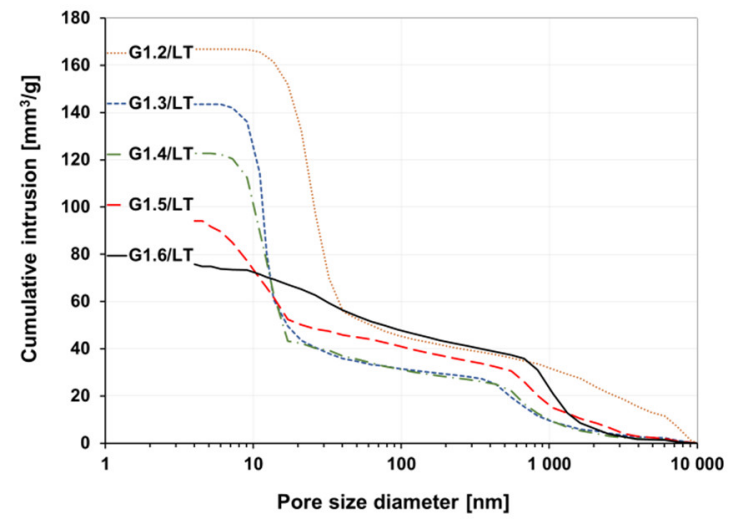

(a)

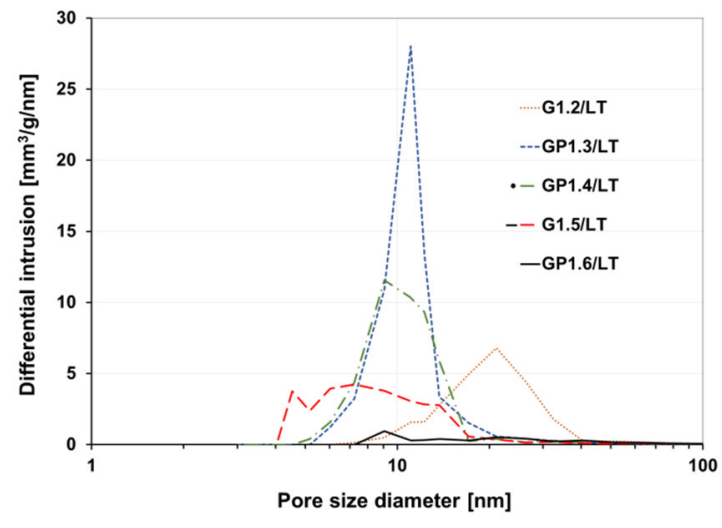

(b)

Figure 6. Cumulative (a) and differential (b) pore volumes for geopolymers made from water glass with different density cured at the ambient temperature.

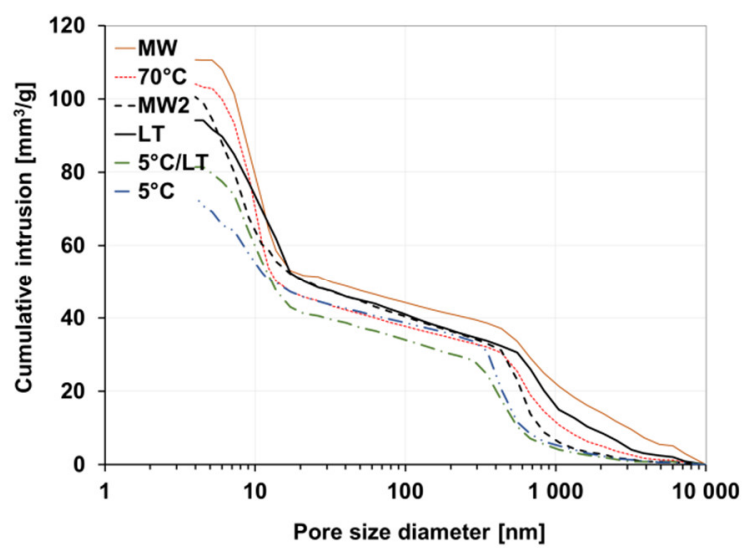

(a)

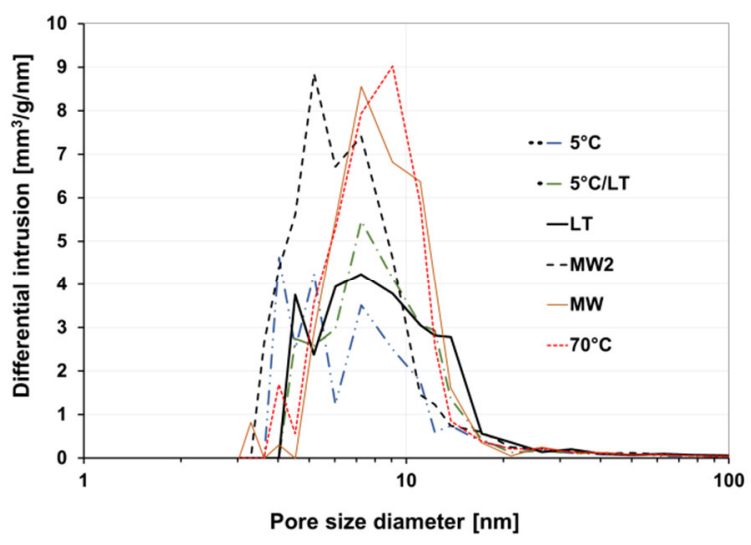

(b)

Figure 7. Cumulative (a) and differential (b) pore volumes for geopolymers made from water glass with density $1.5 \mathrm{~g} \cdot \mathrm{cm}^{-3}$ cured at the various conditions. 
The great influence of the porosity on the GPs compressive strength is in agreement with the literature [22]. Figure 8a shows the interesting dependence of the compressive strength on the pore volume for various GPs with the same chemical composition (water glass density $1.5 \mathrm{~g} \cdot \mathrm{cm}^{-3}$ ) but prepared by various curing methods (red dots labeled as GP1.5/curing variety) and also GPs prepared from various water glass densities and solidified at room temperature (blue squares labeled GP1.2-GP1.6/LT). From this graph, it is apparent that the compressive strength is strongly correlated with the pore volume as also found in Rovnaník [22].

SEM image of the GP 1.5/LT fracture area after the compressive strength measurement (54 MPa) is shown in Figure 8b. In this figure, the geopolymer binder is characterized by a compact morphology revealing some undissolved grains of calcined kaolinite claystone (MK/claystone). The good adhesion of the GP binder to the filler grains is evident-the cracks are developed mainly in the GP binder but the grain/binder interface is almost untouched.

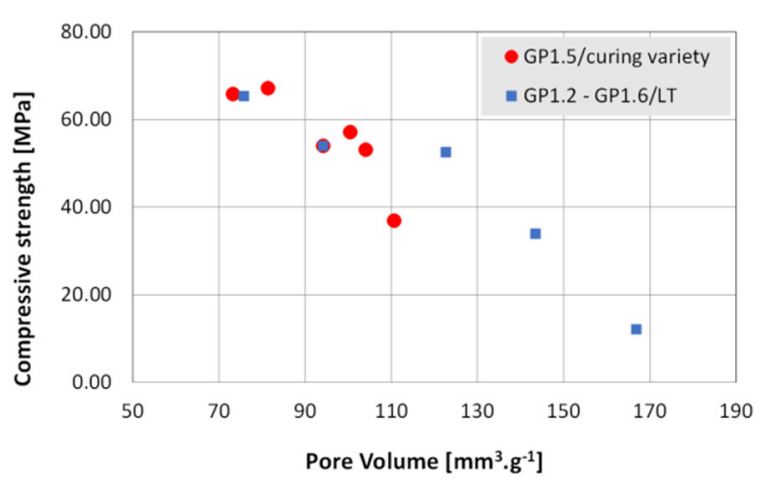

(a)

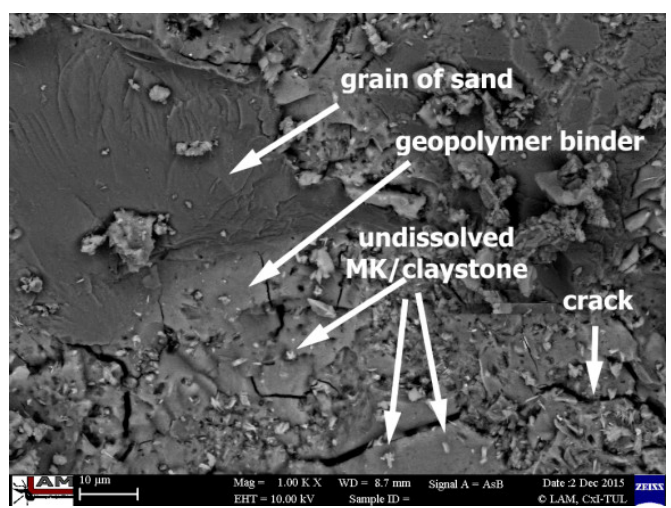

(b)

Figure 8. (a) Dependence of the compressive strength on the pore volume of the geopolymers; (b) SEM image of the GP1.5/LT after the compressive strength measurement. The scale bar is $10 \mu \mathrm{m}$ long.

\section{Conclusions}

The role of the curing conditions, content of water and chemical composition (represented by various water glass density) of kaolinite claystone-based geopolymers on compressive strength, leachability and porosity were studied.

Results lead to these conclusions:

- The correlation between pore volume and compressive strength was confirmed

- The low temperature $\left(5^{\circ} \mathrm{C}\right)$ during solidification has a positive effect on the $\mathrm{GP}$-it increases compressive strength, decreases total pore volume and the leachability of Al.

- The higher density of the water glass used for the sample preparation resulted in lowering the total pore volume and increasing the compressive strength of the samples.

- Sudden increase of the Si and alkali metals leachability was proven in case of the GPs prepared from water glass of the highest density, i.e., $1.6 \mathrm{~g} \cdot \mathrm{cm}^{-3}$ compared to the GP made from water glass with lower densities.

- The most suitable GPs were prepared from water glass with density $1.5 \mathrm{~g} \cdot \mathrm{cm}^{-3}$ followed by solidification at a lowered temperature $\left(5^{\circ} \mathrm{C}\right)$. Such GPs then had the highest compressive strength, low total pore volume, and average pore diameter together with the lowest leachability of the structural elements and ions.

- Although the MW radiation shortened the solidification time to a minimum (26 min), it caused local overheating resulting in higher total pore volume (mainly in case of higher water glass density samples). This resulted in a lowered compressive strength of the MW treated samples. 
Funding: This publication is a result of the project reg. no. FV10420, which is carried out within the programme TRIO of the Ministry of Industry and Trade of the Czech Republic. This project has been funded with support from the state budget through the Ministry of Industry and Trade. The project has been integrated into the National Sustainability Programme I of the Ministry of Education, Youth and Sports of the Czech Republic through the project Development of the UniCRE Centre, Project Code LO1606. The result was achieved using the infrastructure included in the project Efficient Use of Energy Resources Using Catalytic Processes (LM2015039) which has been financially supported by MEYS within the targeted support of large infrastructures.

Conflicts of Interest: The authors declare no conflict of interest.

\section{References}

1. Davidovits, J. Geopolymers and geopolymeric materials. J. Therm. Anal. Calorim. 1989, 35, 429-441. [CrossRef]

2. Komnitsas, K.; Zaharaki, D. Geopolymerisation: A review and prospects for the minerals industry. Miner. Eng. 2007, 20, 1261-1277. [CrossRef]

3. Liew, Y.M.; Kamarudin, H.; Al Bakri, A.M.; Bnhussain, M.; Luqman, M.; Nizar, I.K.; Ruzaidi, C.M.; Heah, C.Y. Optimization of solids-to-liquid and alkali activator ratios of calcined kaolin geopolymeric powder. Constr. Build. Mater. 2012, 37, 440-451. [CrossRef]

4. Singh, N.B. Fly ash-based geopolymer binder: A future construction material. Minerals 2018, 8, 299. [CrossRef]

5. Rosas-Casarez, C.A.; Arredondo-Rea, S.P.; Cruz-Enríquez, A.; Corral-Higuera, R.; Gómez-Soberón, J.M.; Medina-Serna, T.D.J. Influence of size reduction of fly ash particles by grinding on the chemical properties of geopolymers. Appl. Sci. 2018, 8, 365. [CrossRef]

6. Van Jaarsveld, J.G.S. The Physical and Chemical Characterisation of Fly Ash Based Geopolymers. Ph.D. Thesis, The University of Melbourne, Melbourne, Australia, 2000.

7. Temuujin, J.; Riessen, A.V.; MacKenzie, K.J.D. Preparation and characterisation of fly ash based geopolymer mortars. Constr. Build. Mater. 2010, 24, 1906-1910. [CrossRef]

8. Medina-Serna, T.D.J.; Arredondo-Rea, S.P.; Gómez-Soberón, J.M.; Rosas-Casarez, C.A.; Corral-Higuera, R. Effect of curing temperaturein the alkali-activated blast-furnace slag paste and their structural influence of porosity. Adv. Sci. Technol. Res. J. 2016, 10, 74-79. [CrossRef]

9. Yunsheng, Z.; Wei, S.; Qianli, C.; Lin, C. Synthesis and heavy metal immobilization behaviours of slag based geopolymer. J. Hazard. Mater. 2007, 143, 206-213. [CrossRef] [PubMed]

10. Chang, J.J. A study on the setting characteristics of sodium silicate-activated slag pastes. Cem. Concr. Res. 2003, 33, 1005-1011. [CrossRef]

11. Yunsheng, Z.; Wei, S.; Zongjin, L. Composition design and microstructural characterization of calcined kaolin-based geopolymer cement. Appl. Clay Sci. 2010, 47, 271-275. [CrossRef]

12. Granizo, M.L.; Varela, M.T.B.; Martinez-Ramirez, S. Alkali activation of metakaolins: Parameters affecting mechanical, structural and microstructural properties. J. Mater. Sci. 2007, 42, 2934-2943. [CrossRef]

13. Heah, C.Y.; Kamarudin, H.; Mustafa Al Bakri, A.M.; Bnhussain, M.; Luqman, M.; Khairul Nizar, I.; Ruzaidi, C.M.; Liew, Y.M. Study on solids-to-liquid and alkaline activator ratios on kaolin based geopolymers. Constr. Build. Mater. 2012, 35, 912-992. [CrossRef]

14. Perná, I.; Hanzlíček, T.; Šupová, M. The identification of geopolymer affinity in specific cases of clay materials. Appl. Clay Sci. 2014, 102, 213-219. [CrossRef]

15. Xie, J.; Kayali, O. Effect of water content on the development of fly ash-based geopolymers in heat and ambient curing conditions. In Proceedings of the Third International Conference on Sustainable Construction Materials and Technologies, Kyoto, Japan, 18-21 August 2013.

16. Mu, S.; Liu, J.; Liu, J.; Wang, Y.; Shi, L.; Jiang, Q. Property and microstructure of waterborne self-setting geopolymer coating: Optimization effect of $\mathrm{SiO}_{2} / \mathrm{Na}_{2} \mathrm{O}$ molar ratio. Minerals 2018, 8, 162. [CrossRef]

17. Subhash, V.P.; Yuwaraj, M.G.; Sanjay, S.J. Effect of concentration of sodium hydroxide and degree of heat curing on fly ash-based geopolymer mortar. Indian J. Mater. Sci. 2014, 2014, 938789. [CrossRef]

18. Thakur, R.N.; Ghosh, S. Effect of mix composition on compressive strength and microstructure of fly ash based geopolymer composites. ARPN J. Eng. Appl. Sci. 2009, 4, 68-74. 
19. Bortnovsky, O.; Sobalik, S.; Tvaruzkova, Z.; Dedecek, J.; Roubicek, P.; Prudkova, Z.; Svoboda, M. Structure and stability of geopolymer synthesized from kaolinitic and shale clay residues. In Geopolymer, Green Chemistry and Sustainable Development Solutions: Proceedings of the World Congress Geopolymer; Davidovits, J., Ed.; Geopolymer Institute: Saint-Quentin, France, 2005; pp. 81-84.

20. Somaratna, J.; Ravikumar, D.; Neithalath, N. Response of alkali activated fly ash mortars to microwave curing. Cem. Concr. Res. 2010, 40, 1688-1696. [CrossRef]

21. Chindaprasirt, P.; Rattanasak, U.; Taebuanhuad, S. Role of microwave radiation in curing the fly ash geopolymer. Adv. Powder Technol. 2013, 24, 703-707. [CrossRef]

22. Rovnaník, P. Effect of curing temperature on the developmentof hard structure of metakaolin-based geopolymer. Constr. Build. Mater. 2010, 24, 1176-1183. [CrossRef]

23. Patil, S.G.; ManojKumar. Factors Influencing compressive strength of geopolymer concrete. Int. J. Res. Eng. Technol. 2013, 372-375.

24. Duxson, P.; Provis, J.L.; Lukey, G.C.; Mallicoat, S.W.; Kriven, W.M.; van Deventer, J.S.J. Understanding the relationship between geopolymer composition, microstructure and mechanical properties. Colloids Surf. A Physicochem. Eng. Aspects 2005, 269, 47-58. [CrossRef]

25. Duxson, P.; Mallicoat, S.W.; Lukey, G.C.; Kriven, W.M.; van Deventer, J.S.J. The effect of alkali and Si / Al ratio on the development of mechanical properties of metakaolin-based geopolymers. Colloids Surf. A Physicochem. Eng. Aspects 2007, 292, 8-20. [CrossRef]

26. $\mathrm{Xu}, \mathrm{H}$. Geopolymerisation of Aluminosilicate Minerals. Ph.D. Thesis, University of Melbourne, Melbourne, Australia, 2001.

27. Van Jaarsveld, J.G.S.; Van Deventer, J.S.J.; Lukey, G.C. The characterisation of source materials in fly ash-based geopolymers. Mater. Lett. 2003, 57, 1272-1280. [CrossRef]

28. Shen, Y.J.; Zhang, Y.L.; Gao, F.; Yang, G.S.; Lai, X.P. Influence of Temperature on the Microstructure Deterioration of Sandstone. Energies 2018, 11, 1753. [CrossRef]

29. Joseph, B.; Mathew, G. Influence of aggregate content on the behavior of fly ash based geopolymer concrete. Sci. Iranica 2012, 19, 1188-1194. [CrossRef]

30. Kuenzel, C.; Li, L.; Vandeperre, L.; Boccaccini, A.R.; Cheeseman, C.R. Influence of sand on the mechanical properties of metakaolin geopolymers. Constr. Build. Mater. 2014, 66, 442-446. [CrossRef]

31. Latella, B.A.; Perera, D.S.; Durce, D.; Mehrtens, E.G.; Davis, J. Mechanical properties of metakaolin-based geopolymers with molar ratios of $\mathrm{Si} / \mathrm{Al} \approx 2$ and $\mathrm{Na} / \mathrm{Al} \approx 1$. J. Mater. Sci. 2008, 43, 2693-2699. [CrossRef]

32. Granizo, N.; Palomo, A.; Fernandez-Jiménez, A. Effect of temperature and alkaline concentration on metakaolin leaching kinetics. Ceram. Int. 2014, 40, 8975-8985. [CrossRef]

33. Panagiotopoulou, C.; Kontori, E.; Perraki, T.; Kakali, G. Dissolution of aluminosilicate minerals and by-products in alkaline media. J. Mater. Sci. 2007, 42, 2967-2973. [CrossRef]

34. Rouyer, J.; Benavent, V.; Frizon, F.; Poulesquen, A. Influence of geopolymer formulation parameters on the elastic and porous properties over a one-year monitoring. Mater. Lett. 2017, 207, 121-124. [CrossRef]

(C) 2018 by the author. Licensee MDPI, Basel, Switzerland. This article is an open access article distributed under the terms and conditions of the Creative Commons Attribution (CC BY) license (http://creativecommons.org/licenses/by/4.0/). 